\title{
Rates of Public Health Insurance Coverage for Children Rise as Rates of Private Coverage Decline
}

\author{
MICHAEL J. STALEY, JESSICA A. BEAN, AND JESSICA D. ULRICH
}

S ince the 1960s, federal and state programs have sought to increase the number of children covered by health insurance, with growing success. ${ }^{1}$ As a result, the share of children with some type of health insurance has increased steadily, even amid the recent recession. All individuals, and especially children, benefit from having health insurance. ${ }^{2}$ Indeed, children without health insurance are less likely to be immunized and are 70 percent less likely than insured children to receive care for common childhood conditions and emergencies. ${ }^{3}$

Although insurance coverage is critical for healthy outcomes among children, it is important to also look at these trends by type of coverage. For example, while private insurance still covers the majority of children, public insurance is on the rise, covering children who otherwise may not have access to health insurance. ${ }^{4}$ By examining rates of public and private insurance coverage separately, we demonstrate the importance of both types of insurance programs.

This brief uses data from the 2008, 2009, and 2010 American Community Survey to document rates of children's health insurance, both private and public. We track the marked increase in public coverage and the decline in private insurance by region and place type (rural, suburban, and central city). We also provide a brief synopsis of children's transition from private to public insurance coverage during the previous three years.

\section{Overall Rates of Coverage Continued to Rise in 2010}

Between 2009 and 2010, rates of health insurance coverage among children increased in all place types by about one-half a percentage point (see Table 1). This increase continues the trend of rising coverage since 2008, with a national aggregate increase of 1.9 percentage points across the three years (2008 to 2010). The largest regional increase in coverage occurred in the South, where rates rose by more than a full percent-

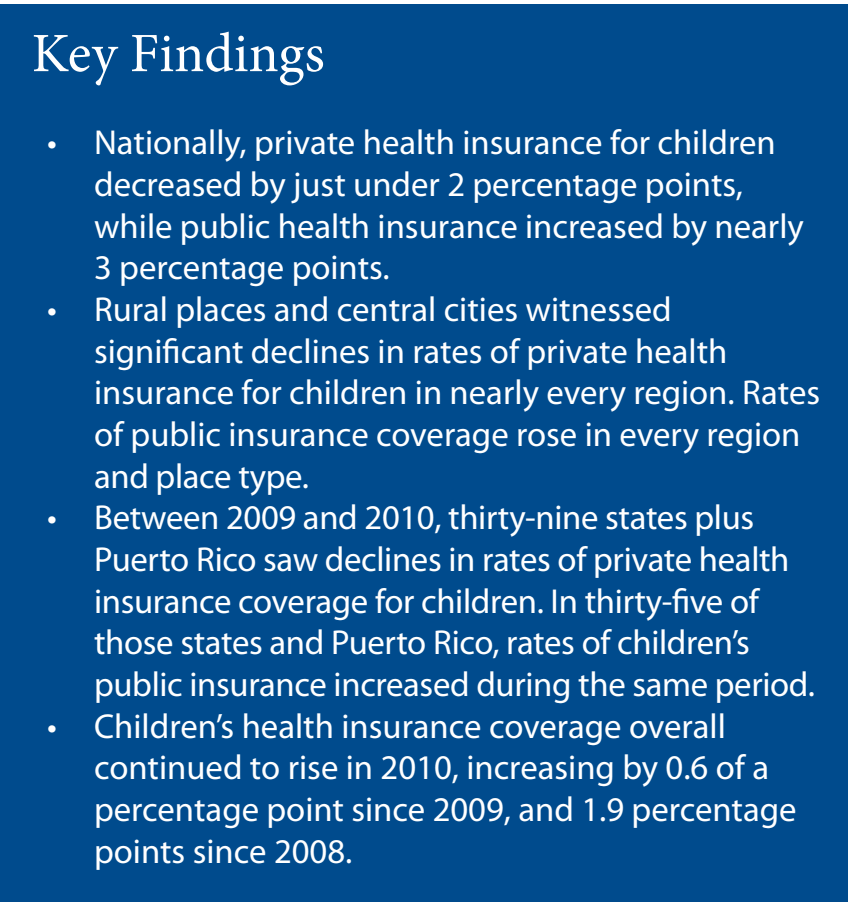

age point since 2009 and 2.7 percentage points since 2008 . In contrast, rates in the Northeast (the region with the highest rates of coverage since 2008) remained flat between 2009 and 2010. Children's health insurance coverage increased in nine states between 2009 and 2010, rising by more than two percentage points in one state (Florida). Following national trends, the percentage of insured children did not significantly decline in any state.

From 2009 to 2010, the type of coverage changed significantly, with a 1.9 percentage point decline in the share of children covered by private insurance and a 3.0 percentage point increase in public insurance. During that year, thirty-nine states and Puerto Rico saw declines in the percentage of children covered by private health insurance. Two states, Hawaii and Vermont, saw declines greater than 5 percentage points. Meanwhile, 
Table 1. Percentage Point Change in Health Insurance Coverage for Persons Under Age 18

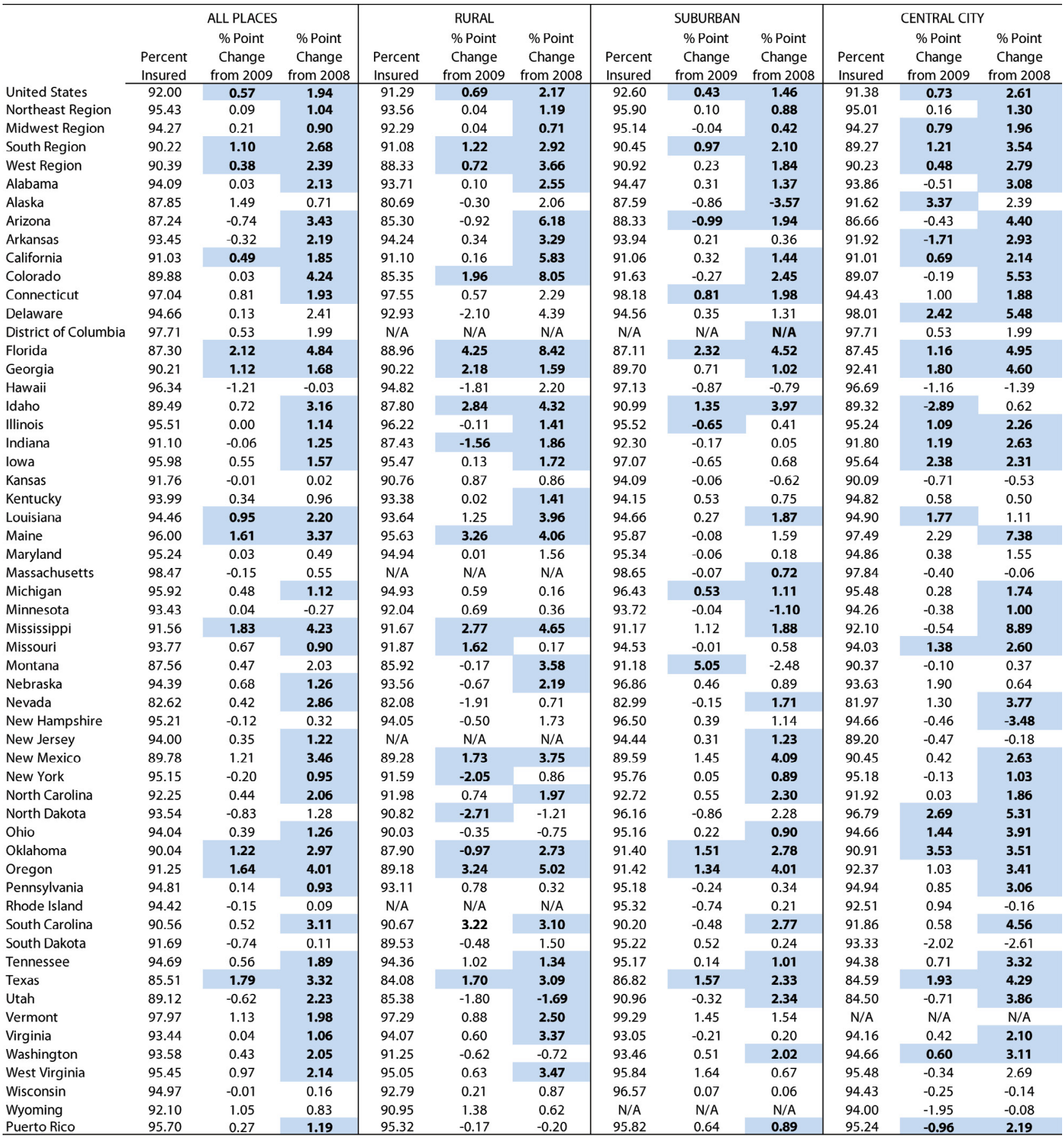

N/A= Not applicable.

1. The bold and shaded font indicates statistical significance $(p<0.05)$

2. Levels of urbanization are defined as follows: Rural consists of American Community Survey geographic components "not in metropolitan or micropolitan statistical area" and "in micropolitan statistical area"; suburban includes "in metropolitan statistical area-not in principal city" and central city includes "in metropolitan statistical areain principal city.”

Source: American Community Survey, 2008, 2009, and 2010. 
thirty-five of those states and Puerto Rico saw increases in public coverage. ${ }^{5}$ Thus, the decreases in rates of private coverage are nearly proportionate to the increases in public insurance in most states. This suggests that states' public insurance programs were able to provide coverage for children who lost their private insurance in 2010 and who would otherwise be uninsured. ${ }^{6}$

During this one-year period, the most dramatic shifts from private to public were in central cities. Rates of private insurance coverage shrunk by more than 5 percentage points in the central cities of ten states and in Puerto Rico. Twelve states and Puerto Rico saw increases in public insurance of this magnitude.

The pattern described above for 2009-2010 echoes the shift from private to public plans in the previous year. Between 2008 and 2010 (not shown), private insurance decreased by 4.5 percentage points and public insurance increased by 7.9 percentage points. ${ }^{7}$ During this period, forty-six states, plus Puerto Rico and Washington, DC, saw declines in private health insurance coverage rates for children, and forty-two states, plus Puerto Rico and Washington, DC, experienced increases in public coverage. ${ }^{8}$ Again, the most drastic increases in public insurance were found in central cities. Twenty-one states plus Washington, DC, registered increases of 10 percentage points or more in metropolitan centers; of these places, just three saw declines in private insurance of the same magnitude (see Table 2).

\section{Is Public Insurance Displacing Private Insurance?}

At first glance, the trend of declining private insurance coverage for children and growing rates of public insurance might suggest that public coverage is "crowding out" private health insurance at an alarming rate. "Crowd out" occurs when the incentives are such that families opt out of costly private coverage options (usually provided by their employers) in favor of less expensive public coverage.

Crowd-out indicates that consumers have a choice between private and public coverage. However, economic evidence suggests that the children who lost private coverage would have had no insurance if they were not eligible for public coverage. ${ }^{10}$ Child poverty rates rose nearly two percentage points in 2010, suggesting that children may be increasingly (and now perhaps only) eligible for public insurance. ${ }^{11}$ The unemployment rate also remains high, at 8.6 percent in November 2011, which suggests that many families may no longer have private employer-based insurance. ${ }^{12}$ It is also likely that many parents are no longer working the same types of jobs since the recession, and may now be working part-time or in a different sector. This change in the labor market may leave dependent children ineligible for private coverage. Finally, employers continue to look for ways to reduce costs, including offering fewer benefits to employees. Therefore, families may be enrolling their children in public insurance because enrollment in a private plan is no longer an option..$^{13}$

\section{Policy Implications}

The Joint Select Committee on Deficit Reduction failed to reach an agreement by November 23, 2011 on a plan for reducing the federal deficit. As required by the Budget Control Act of 2011, automatic across-the-board spending cuts will go into effect in January 2013, under a process called sequestration. Under the current sequestration law, state children's health insurance programs (SCHIP) and Medicaid would be protected from these automatic cuts. ${ }^{14}$ However, the existing sequestration plan requires that half of the budget cuts come from the military, a mandate that is unpopular with many members of Congress. Indeed, it appears there may be an effort to modify the sequestration law in order to reduce required cuts to the military, possibly before the close of 2011 . If enacted, a reformulated law could substitute deep budget cuts to social programs including SCHIP and Medicaid programs in order to reduce the cuts to the military.

In addition to the uncertainty of funding for children's health insurance programs at the federal level, states will continue to wield significant influence and control over these programs. Amidst widespread budget deficits, at least twenty states have already made deep cuts in health care services, including freezing enrollment, limiting services, and constraining eligibility requirements (thus dropping enrollees). ${ }^{15}$ In addition, the most significant effects of the Patient Protection and Affordable Care Act (PPACA) have yet to be enacted, as the legislation does not take full effect until 2014. Even after the PPACA has been fully implemented, policy experts are uncertain how it will affect rates of private and public health insurance. However, the uncertainty and delay of health care reform and the lingering effects of the recession indicate that the shift from private to public coverage is not likely to cease in the immediate future.

While there are still children who would benefit from insurance coverage in the United States, public policy has been largely successful in providing coverage to children who would otherwise be uninsured. ${ }^{16}$ Children who have health insurance have more favorable health outcomes than those who do not, with long-term benefits that carry into adulthood. ${ }^{17}$ As the expense of care continues to rise, legislators, insurers, and health care professionals should consider alternative measures for reducing health care costs, such as renegotiating reimbursement rates for providers and reducing the cost of pharmaceuticals, thereby slowing the rise of private health care premiums. Such measures may also slow the increasing rates of enrollment in public insurance.

The increase in the overall number of children enrolled in some type of health insurance coverage is a positive step in ensuring the health of the next generation of young adults in the United States. Children benefit when local and federal legislators support public insurance programs that cover preventive and emergent care for those who would otherwise have no means to pay for such services. 
Table 2. Percentage Point Change in Private and Public Health Insurance Coverage, for Persons Under Age 18

\begin{tabular}{|c|c|c|c|c|c|c|c|c|c|c|c|c|c|c|c|c|}
\hline & \multicolumn{4}{|c|}{ ALL PLACES } & \multicolumn{4}{|c|}{ RURAL } & \multicolumn{4}{|c|}{ SUBURBAN } & \multicolumn{4}{|c|}{ CENTRAL CITY } \\
\hline & $\begin{array}{l}\text { Percent } \\
\text { Private }\end{array}$ & $\begin{array}{c}\% \text { Point } \\
\text { Change } \\
\text { from } 2009\end{array}$ & $\begin{array}{l}\text { Percent } \\
\text { Public }\end{array}$ & $\begin{array}{l}\% \text { Point } \\
\text { Change } \\
\text { from } 2009\end{array}$ & $\begin{array}{l}\text { Percent } \\
\text { Private }\end{array}$ & $\begin{array}{l}\% \text { Point } \\
\text { Change } \\
\text { from } 2009\end{array}$ & $\begin{array}{l}\text { Percent } \\
\text { Public }\end{array}$ & $\begin{array}{c}\% \text { Point } \\
\text { Change } \\
\text { from } 2009\end{array}$ & $\begin{array}{l}\text { Percent } \\
\text { Private }\end{array}$ & $\begin{array}{l}\% \text { Point } \\
\text { Change } \\
\text { from } 2009\end{array}$ & $\begin{array}{c}\text { Percent } \\
\text { Public }\end{array}$ & $\begin{array}{c}\% \text { Point } \\
\text { Change } \\
\text { from } 2009\end{array}$ & $\begin{array}{l}\text { Percent } \\
\text { Private }\end{array}$ & $\begin{array}{l}\% \text { Point } \\
\text { Change } \\
\text { from } 2009\end{array}$ & $\begin{array}{l}\text { Percent } \\
\text { Public }\end{array}$ & $\begin{array}{l}\% \text { Point } \\
\text { Change } \\
\text { from } 2009\end{array}$ \\
\hline United States & 59.60 & -1.93 & 36.23 & 2.96 & 53.73 & -1.36 & 42.04 & 2.34 & 67.00 & \begin{tabular}{|c|}
-1.64 \\
\end{tabular} & 29.10 & 2.48 & 50.31 & -2.84 & 44.89 & 3.99 \\
\hline Northeast Region & 66.40 & -2.05 & 33.72 & 2.67 & 61.51 & -1.45 & 37.73 & 1.73 & 75.95 & -1.28 & 24.06 & 1.83 & 47.58 & -4.76 & 52.89 & 5.51 \\
\hline Midwest Region & 64.32 & -1.73 & 34.28 & 2.34 & 61.62 & -1.59 & 36.15 & 1.95 & 73.00 & -1.91 & 25.96 & 2.19 & 50.77 & -1.90 & 47.51 & 2.95 \\
\hline South Region & 54.76 & -1.97 & 38.62 & 3.41 & 46.50 & -1.44 & 48.13 & 2.81 & 61.51 & -1.54 & 31.75 & 2.79 & 48.22 & -3.20 & 44.31 & 4.75 \\
\hline West Region & 58.21 & -2.01 & 36.01 & 3.04 & 54.39 & -1.02 & 38.46 & 2.36 & 62.74 & -2.02 & 32.00 & 2.86 & 53.66 & -2.14 & 40.10 & 3.19 \\
\hline Alabama & 56.67 & -2.22 & 41.21 & 2.91 & 50.20 & -2.91 & 47.07 & 2.36 & 64.14 & -1.45 & 33.88 & 2.69 & 50.76 & -3.08 & 46.51 & 3.18 \\
\hline Alaska & 61.88 & 0.19 & 32.20 & 2.80 & 44.57 & 4.97 & 42.28 & -3.23 & 69.10 & -0.50 & 26.05 & 0.39 & 65.92 & -2.03 & 31.32 & 6.85 \\
\hline Arizona & 53.90 & -1.10 & 37.48 & 1.31 & 43.71 & -0.86 & 45.67 & 0.56 & 62.41 & -1.01 & 30.87 & 1.17 & 48.56 & -0.70 & 41.41 & 0.99 \\
\hline Arkansas & 46.85 & -2.93 & 51.05 & 3.32 & 42.06 & -1.59 & 55.61 & 0.98 & 54.97 & -0.44 & 43.83 & 3.15 & 44.34 & -7.19 & 51.46 & 4.92 \\
\hline California & 55.47 & -2.22 & 39.12 & 3.35 & 50.79 & -6.11 & 46.08 & 7.04 & 58.26 & -2.61 & 36.41 & 3.60 & 52.63 & -1.61 & 41.77 & 2.87 \\
\hline Colorado & 64.77 & -1.95 & 27.90 & 2.39 & 58.57 & 6.02 & 29.67 & -2.74 & 72.78 & -2.95 & 21.83 & 3.29 & 56.30 & -3.12 & 35.00 & 2.48 \\
\hline Connecticut & 70.78 & -2.40 & 29.28 & 3.64 & 73.28 & 0.98 & 26.77 & 0.07 & 79.55 & -0.74 & 21.32 & 1.86 & 51.08 & -6.33 & 47.17 & 7.90 \\
\hline Delaware & 63.28 & -3.37 & 36.37 & 4.73 & 44.47 & -12.84 & 53.09 & 11.54 & 73.99 & 1.26 & 24.51 & -0.87 & 33.58 & -12.92 & 69.29 & 17.45 \\
\hline District of Columbia & 53.55 & 2.21 & 55.01 & 3.83 & N/A & $\mathrm{N} / \mathrm{A}$ & N/A & $\mathrm{N} / \mathrm{A}$ & N/A & $N / A$ & N/A & $\mathrm{N} / \mathrm{A}$ & 53.55 & 2.21 & 55.01 & 3.83 \\
\hline Florida & 52.80 & -1.65 & 37.36 & 4.33 & 40.04 & -3.91 & 51.78 & 9.35 & 55.15 & -0.92 & 34.48 & 3.50 & 49.28 & -3.04 & 41.69 & 5.15 \\
\hline Georgia & 55.12 & -2.17 & 37.88 & 3.56 & 42.41 & -1.90 & 50.85 & 4.40 & 60.68 & -1.75 & 31.50 & 2.45 & 45.87 & -4.01 & 49.21 & 6.03 \\
\hline Hawaii & 69.39 & -5.30 & 31.58 & 3.15 & 56.09 & -9.54 & 41.75 & 4.27 & 77.85 & -1.40 & 24.47 & 0.22 & 68.37 & -9.25 & 33.04 & 8.33 \\
\hline Idaho & 62.83 & 0.66 & 32.15 & 1.86 & 57.25 & 0.85 & 35.48 & 3.81 & 70.07 & 3.04 & 25.70 & -1.83 & 58.84 & -3.81 & 36.67 & 4.36 \\
\hline Illinois & 60.10 & -1.80 & 38.57 & 1.64 & 60.13 & 0.19 & 41.33 & -1.03 & 67.19 & -2.88 & 31.33 & 2.11 & 48.23 & -1.09 & 49.76 & 2.16 \\
\hline Indiana & 60.86 & -3.12 & 34.03 & 3.59 & 57.51 & -2.40 & 34.19 & 1.10 & 70.97 & -2.51 & 24.87 & 2.97 & 47.99 & -4.10 & 47.55 & 5.72 \\
\hline lowa & 70.12 & -2.08 & 31.59 & 2.48 & 67.37 & -5.30 & 36.07 & 6.56 & 81.83 & -0.63 & 19.11 & -0.76 & 62.67 & 1.41 & 38.06 & 0.29 \\
\hline Kansas & 68.31 & 0.04 & 26.56 & 0.15 & 62.18 & -0.84 & 32.71 & 2.64 & 79.63 & 0.23 & 17.73 & 0.30 & 61.39 & 0.77 & 30.11 & -2.98 \\
\hline Kentucky & 58.49 & 0.06 & 39.52 & 1.57 & 48.93 & 0.44 & 48.28 & 0.31 & 70.02 & 0.77 & 28.44 & 1.26 & 57.74 & -1.54 & 41.02 & 4.15 \\
\hline Louisiana & 47.56 & -3.47 & 50.87 & 5.24 & 41.96 & -1.61 & 55.96 & 3.43 & 53.97 & -3.85 & 45.01 & 5.14 & 42.14 & -4.99 & 56.49 & 8.05 \\
\hline Maine & 59.55 & -2.18 & 41.34 & 2.80 & 53.09 & -0.63 & 48.02 & 2.08 & 67.44 & -3.34 & 32.59 & 2.31 & 52.56 & -4.33 & 51.88 & 9.22 \\
\hline Maryland & 68.36 & -2.39 & 29.80 & 2.77 & 67.30 & 1.86 & 32.24 & 0.60 & 72.49 & -2.07 & 25.67 & 2.45 & 48.51 & -6.34 & 48.63 & 5.46 \\
\hline Massachusetts & 72.58 & -2.75 & 31.49 & 2.89 & N/A & $N / A$ & N/A & $\mathrm{N} / \mathrm{A}$ & 77.59 & -2.70 & 26.45 & 2.62 & 55.43 & -3.18 & 48.77 & 3.98 \\
\hline Michigan & 61.82 & -2.29 & 39.71 & 3.50 & 59.10 & -2.02 & 42.07 & 2.56 & 71.01 & -2.89 & 30.41 & 3.86 & 44.16 & -2.66 & 57.21 & 4.13 \\
\hline Minnesota & 73.23 & -0.85 & 24.74 & 1.71 & 69.17 & 1.37 & 28.52 & -0.11 & 79.50 & -1.45 & 18.48 & 2.54 & 62.29 & -2.70 & 35.86 & 2.54 \\
\hline Mississippi & 43.94 & -3.18 & 50.63 & 4.60 & 37.62 & -3.15 & 57.62 & 6.38 & 56.99 & -2.28 & 36.15 & 1.54 & 36.50 & -6.52 & 59.55 & 6.04 \\
\hline Missouri & 63.55 & -0.98 & 33.42 & 1.74 & 53.74 & 0.98 & 41.56 & 0.02 & 71.94 & -1.64 & 25.08 & 1.35 & 52.91 & -1.49 & 45.08 & 3.93 \\
\hline Montana & 60.82 & -0.45 & 31.63 & 2.94 & 58.05 & -1.57 & 31.36 & 2.39 & 70.29 & 3.44 & 25.45 & 1.04 & 63.79 & 0.82 & 35.60 & 5.40 \\
\hline Nebraska & 68.31 & -0.87 & 31.04 & 3.66 & 66.50 & -2.36 & 31.62 & 2.60 & 84.26 & -0.05 & 15.43 & 1.06 & 59.33 & -2.03 & 40.74 & 8.02 \\
\hline Nevada & 61.39 & -3.93 & 24.19 & 4.15 & 65.98 & -5.72 & 21.05 & 7.13 & 64.71 & -1.79 & 20.11 & -0.20 & 56.38 & -6.62 & 29.38 & 8.73 \\
\hline New Hampshire & 71.66 & -2.39 & 26.34 & 1.84 & 64.08 & -7.05 & 33.02 & 6.34 & 81.58 & 0.14 & 17.13 & -0.94 & 57.76 & -3.93 & 40.48 & 4.20 \\
\hline New Jersey & 70.16 & -1.90 & 26.73 & 2.64 & N/A & $N / A$ & N/A & N/A & 73.52 & -1.16 & 23.87 & 2.00 & 33.59 & -17.08 & 57.95 & 15.67 \\
\hline New Mexico & 45.49 & -0.78 & 49.50 & 3.60 & 43.17 & 0.68 & 52.68 & 2.80 & 42.98 & -1.78 & 52.14 & 5.86 & 49.99 & -1.53 & 44.66 & 3.22 \\
\hline New York & 62.34 & -1.86 & 37.60 & 2.37 & 63.83 & -0.44 & 32.86 & -1.39 & 78.05 & -0.54 & 21.45 & 1.25 & 47.73 & -3.93 & 53.05 & 4.59 \\
\hline North Carolina & 55.96 & -2.68 & 39.41 & 3.37 & 48.12 & -2.36 & 47.15 & 3.01 & 62.22 & -1.47 & 33.36 & 2.11 & 55.26 & -4.36 & 39.17 & 4.38 \\
\hline North Dakota & 78.33 & -0.50 & 20.66 & 1.45 & 73.51 & -3.04 & 21.02 & 0.62 & 87.66 & -0.10 & 12.13 & -0.39 & 81.26 & 4.28 & 26.08 & 4.58 \\
\hline Ohio & 63.85 & -1.57 & 34.77 & 2.30 & 60.01 & -1.80 & 36.50 & 2.54 & 73.48 & -1.44 & 25.64 & 1.83 & 43.44 & -2.55 & 55.29 & 3.61 \\
\hline Oklahoma & 52.01 & -1.68 & 41.34 & 2.67 & 46.14 & -0.80 & 45.62 & -0.16 & 59.33 & -3.86 & 36.24 & 6.03 & 49.79 & 0.06 & 43.18 & 2.30 \\
\hline Oregon & 62.43 & -1.68 & 33.27 & 4.50 & 55.86 & -0.05 & 37.79 & 4.70 & 66.28 & -0.88 & 29.15 & 2.93 & 61.27 & -3.83 & 34.86 & 5.26 \\
\hline Pennsylvania & 65.94 & -1.95 & 34.75 & 2.84 & 61.17 & -0.73 & 38.98 & 2.54 & 74.91 & -1.00 & 25.65 & 1.63 & 42.97 & -5.62 & 57.86 & 5.93 \\
\hline Rhode Island & 68.02 & -0.93 & 32.88 & 2.21 & $\mathrm{~N} / \mathrm{A}$ & N/A & N/A & $\mathrm{N} / \mathrm{A}$ & 72.38 & -3.38 & 29.08 & 3.52 & 58.73 & 3.61 & 40.95 & -0.07 \\
\hline South Carolina & 54.98 & -2.14 & 38.59 & 2.64 & 46.13 & 0.69 & 48.17 & 3.11 & 58.91 & -2.49 & 34.02 & 1.86 & 52.29 & -5.05 & 42.14 & 4.55 \\
\hline South Dakota & 67.69 & 0.66 & 30.76 & 0.03 & 61.32 & -0.18 & 34.40 & 0.77 & 82.19 & 5.67 & 18.90 & -4.37 & 69.29 & -1.46 & 30.55 & 0.06 \\
\hline Tennessee & 59.24 & -1.34 & 39.58 & 2.17 & 52.60 & -3.00 & 46.25 & 3.77 & 69.41 & -0.91 & 28.81 & 0.33 & 52.15 & -0.71 & 46.73 & 2.61 \\
\hline Texas & 49.38 & -1.90 & 38.78 & 3.87 & 44.62 & 0.28 & 42.31 & 1.97 & 56.91 & -1.62 & 32.20 & 3.52 & 43.24 & -3.14 & 44.24 & 4.97 \\
\hline Utah & 71.64 & -3.13 & 20.77 & 2.87 & 63.68 & -4.18 & 25.28 & 2.03 & 76.86 & -1.96 & 17.12 & 2.03 & 56.93 & -6.01 & 30.62 & 4.86 \\
\hline Vermont & 56.02 & -6.79 & 47.77 & 6.83 & 51.93 & -6.91 & 52.39 & 6.57 & 65.57 & -7.06 & 38.59 & 9.11 & $\mathrm{~N} / \mathrm{A}$ & $\mathrm{N} / \mathrm{A}$ & $\mathrm{N} / \mathrm{A}$ & N/A \\
\hline Virginia & 71.91 & -1.34 & 24.40 & 1.77 & 57.91 & -2.02 & 39.95 & 2.07 & 77.15 & -1.02 & 18.40 & 1.31 & 65.18 & -2.45 & 32.82 & 3.94 \\
\hline Washington & 62.12 & -2.10 & 36.30 & 2.90 & 50.96 & -2.22 & 45.40 & 0.62 & 67.07 & -1.40 & 31.26 & 2.73 & 57.02 & -2.83 & 42.20 & 3.29 \\
\hline West Virginia & 56.93 & -2.69 & 43.12 & 2.54 & 54.34 & 1.32 & 44.87 & -2.58 & 60.51 & -5.98 & 41.12 & 7.27 & 52.72 & -5.39 & 47.45 & 6.93 \\
\hline Wisconsin & 67.20 & -3.03 & 32.90 & 3.61 & 63.16 & -4.54 & 35.28 & 4.65 & 79.89 & -1.34 & 21.82 & 2.74 & 51.24 & -3.71 & 46.89 & 2.50 \\
\hline Wyoming & 63.18 & -2.91 & 31.34 & 2.27 & 65.69 & -0.23 & 28.90 & 0.85 & N/A & $\mathrm{N} / \mathrm{A}$ & $\mathrm{N} / \mathrm{A}$ & $\mathrm{N} / \mathrm{A}$ & 58.35 & -11.07 & 36.38 & 5.56 \\
\hline Puerto Rico & 40.71 & -3.38 & 58.18 & 3.10 & 33.64 & -2.30 & 65.13 & -1.49 & 41.61 & -2.68 & 57.58 & 3.05 & 39.69 & -5.75 & 58.99 & 4.73 \\
\hline
\end{tabular}

N/A $=$ Not applicable

1. The bold and shaded font indicates statistical significance $(p<0.05)$.

2. Levels of urbanization are defined as follows: Rural consists of American Community Survey geographic components "not in metropolitan or micropolitan statistical area" and "in micropolitan statistical area"; suburban includes "in metropolitan statistical area-not in principal city" and central city includes "in metropolitan statistical area-in principal city." Source: American Community Survey, 2009 and 2010. 


\section{Data}

The analysis is based on U.S. Census Bureau estimates from the 2008, 2009, and 2010 American Community Survey. Tables were produced by aggregating information from detailed tables available on American Factfinder. ${ }^{18}$ These estimates are meant to offer perspective on children's health insurance, but because they are based on survey data, caution must be used in comparing across years or places, as the margin of error may indicate that seemingly disparate numbers fall within sampling error. All differences highlighted in this brief are statistically significant at the 95 percent level.

\section{EN D N O TES}

1. D. Bae, "Introduction to the State Children's Health Insurance Program," Research Brief No. 2 (Princeton, NJ: Robert Wood Johnson Foundation, 2007).

2. M.R. Cousineau, G.D. Stevens, and T.A. Pickering, "Preventable Hospitalizations among Children in California Counties after Child Health Insurance Expansion Initiatives," Medical Care, vol. 45 (2008): 142-47. See also C. Hoffman and J. Paradise, "Health Insurance and Access to Health Care in the United States," Annals of the NY Academy of Science, vol. 1136 (2008): 149-60.

3. Jill Bernstein, Deborah Collet, and Stephanie Peterson, "How Does Health Insurance Coverage Improve Health Outcomes?" Issue Brief No. 1 (Washington, DC: Mathematica Policy Research, 2010), p. 1.

4. Jessica A. Bean and Michael J. Staley, "Total Children Covered by Health Insurance Increased in 2009: Significant Shifts from Private to Public Plans in Many States," Issue Brief No. 34 (Durham, NH: Carsey Institute, University of New Hampshire, 2011).

5. Hawaii, Maine, New Hampshire, and West Virginia experienced significant decreases in private coverage, but not increases in public coverage between 2009 and 2010.

6. H.L. Shaefer, C.M. Grogan, and H.A. Pollack, "Who Transitions from Private to Public Health Insurance? Lessons from Expansions of the State Children's Health Insurance Program," Journal of Health Care for the Poor and Underserved, vol. 22 (2011): 359-370; L. Dubay and G. Kenney, "The Impact of CHIP on Children's Insurance Coverage: An Analysis Using the National Survey of American Families," Health Research and Educational Trust (December 2009): 2040-59; G.M. Kenney et al., "Who and Where Are the Children Yet to Enroll in Medicaid and the Children's Health Insurance Program?" Health Affairs, vol. 29 (2010): 1920-1929.

7. For 2008 estimates, please refer to Bean and Staley, "Total Children Covered by Health Insurance Increased in 2009.”
8. Illinois, Michigan, Oklahoma, and West Virginia experienced significant decreases in private coverage, but not increases in public coverage between 2008 and 2010.

9. S. Jaffe, "A public health insurance plan: should Americans be able to enroll in a newly created publicly administered health insurance option as the nation works to expand health coverage? (Health Policy Brief)," Health Affairs (19 June 2009).

10. Shaefer, Grogan, and Pollack, "Who Transitions from Private to Public Health Insurance?"; Dubay and Kenney, “The Impact of CHIP on Children's Insurance Coverage."; Kenney et al., "Who and Where Are the Children Yet to Enroll in Medicaid and the Children's Health Insurance Program?"

11. Marybeth J. Mattingly, Jessica A. Bean, and Andrew Schaefer, "One Million Additional Children in Poverty Since 2009: 2010 Data Reveal Nearly One in Four Southern Children Now Live in Poverty," Issue Brief no. 37 (Durham, NH: Carsey Institute, University of New Hampshire, 2011).

12. The recession began in December 2007. In November 2007, the unemployment rate was 4.7 percent. Bureau of Labor Statistics, "Unemployment Rate," Labor Force Statistics from the Current Population Survey (Washington, DC: Bureau of Labor Statistics, 2011). Andrew Villegas, "Employer-Based Insurance Explained," Kaiser Health News September 28 (Washington, DC: Henry J. Kaiser Family Foundation, 2009).

13. Private insurance may have become unavailable because the parent or guardian became unemployed, because their employer dropped the benefit, or because insurance premiums outpaced cost of living increases in wages. See Marilyn Werber Serafini, "Less Competition, Higher Premiums: Is Consolidation in the Health Insurance Industry Causing Premiums to Soar?" National Journal (March 20, 2010), available at http://conventions.nationaljournal.com/njmagazine/id_20100320_7716.php.

14. K. and L. Gates, "The Impact of the Federal Deficit Reduction on Poor Families," Report DC-9553187 (Seattle, WA: Marguerite Casey Foundation).

15. Erica Williams, Michael Leachman, and Nicholas Johnson, "State Budget Cuts in the New Fiscal Year Are Unnecessarily Harmful: Cuts Are Hitting Hard at Education, Health Care, and State Economics," Report, July 28 (Washington, DC: Center on Budget and Policy Priorities).

16. Bae, "Introduction to the State Children's Health Insurance Program."

17. S. Haas, M.M. Glymour, and L.F. Berkman, "Childhood Health and Labor Market Inequality over the Life Course," Journal of Health and Social Behavior, vol. 52, no. 3 (2011): 298-313.

18. Available at http://factfinder2.census.gov. 


\section{A B OUT THE AUTHORS}

Michael J. Staley is a doctoral student in sociology at the University of New Hampshire and a research assistant at the Carsey Institute (michael.staley@unh.edu).

Jessica Bean is a vulnerable families research associate at the Carsey Institute (jessica.bean@unh.edu).

Jessica D. Ulrich is a doctoral student in sociology at the University of New Hampshire and a research assistant at the Carsey Institute (jessicad.ulrich@gmail.com).

\section{A C K N O W L E D G M E N T S}

The authors would like to thank Bruce Mallory, Beth Mattingly, Amy Sterndale, and Laurel Lloyd Earnshaw at the Carsey Institute for helpful comments and suggestions; and Barbara Ray at Hiredpen for editorial assistance. Special thanks to Michelle Stransky and Jennifer Clayton for analytic support.

\section{A UNIVERSITY Aiv of NEW HAMPSHIRE}

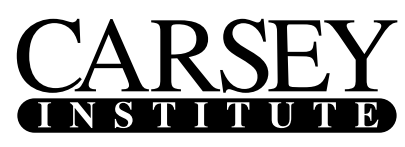

Building knowledge for families and communities

The Carsey Institute conducts policy research on vulnerable children, youth, and families and on sustainable community development. We give policy makers and practitioners timely, independent resources to effect change in their communities.

This work was supported by the Annie E. Casey Foundation, the W. K. Kellogg Foundation, and an anonymous donor.

Huddleston Hall

73 Main Street

Durham, NH 03824

$(603) 862-2821$

www.carseyinstitute.unh.edu 